\title{
HOUSEHOLDS AND FAMILIES IN ESTONIAN POPULATION
}

\author{
Ene-Margit TitT \\ Institute of Mathematics and Statistics, University of Tartu, Tartu, Estonia
}

\begin{abstract}
The statistical distribution of households and families by their size and structure can be received from population and household censuses, but it is also important to know this information between the censuses, as changes during the ten-year period can be quite remarkable. It is demonstrated that, since the last census in Estonia in 2011, the share of older age-groups has increased and the rate of children - decreased. The age at first marriage has increased for men and women respectively by 3 and 4 months per year. Consequently, the share of young people living without a partner has increased, but the process is different in men and women. The number of divorces has dropped, but this seems to be caused by the decline of marriages during the last decades. The age of women giving birth has also increased. During the last years, the number of third children has increased, but the number of first children has decreased. The distribution of households by their types was also studied and is presented in Table 1. It is evident that about one-sixth of the population lives alone; single-person households form the most numerous household type in present-day Estonia. From all households containing a couple, somewhat more than two-thirds are households with a married couple, others are households with a cohabiting couple. In average, the first ones are much older than the second ones. The number of households where two or more generations live together is marginal.
\end{abstract}

Keywords: population size; age of first marriage; divorce rate; birth order; household type

It is important to know the current statistical distribution of households and families by their size and structure. This information can be received from 
population and household censuses. But the problem is that the period of censuses is ten years nowadays, which means that between the censuses the exact data are usually not available, and out-of-date data are used if necessary.

To avoid this problem, a model has been created that gives the estimated values for all household and family types for each year between two censuses. As input for this model, we also use data from different surveys alongside the census data and data from registers.

\section{CHANGE OF POPULATION SIZE IN DIFFERENT AGE GROUPS}

Since 2015, the population size in Estonia has been estimated using the residency index that uses more than 20 administrative indexes to establish the persons living permanently in Estonia each year, that is, are residents of the state. It is interesting that the change has not been linear, but, in 2015, a turn took place: the population size that had decreased for more than 25 years started to increase. The reason for this turn is the change in external migration: Estonia, which was an emigration country for long time, has, due to the improved economic situation, gained the status of an immigration country. Also, many people who had emigrated in earlier years, have now returned. The change in population size is well described with help of a quadratic model, see Figure 1. From 2010 , the population size has decreased by $0.6 \%$ ( 8500 persons).

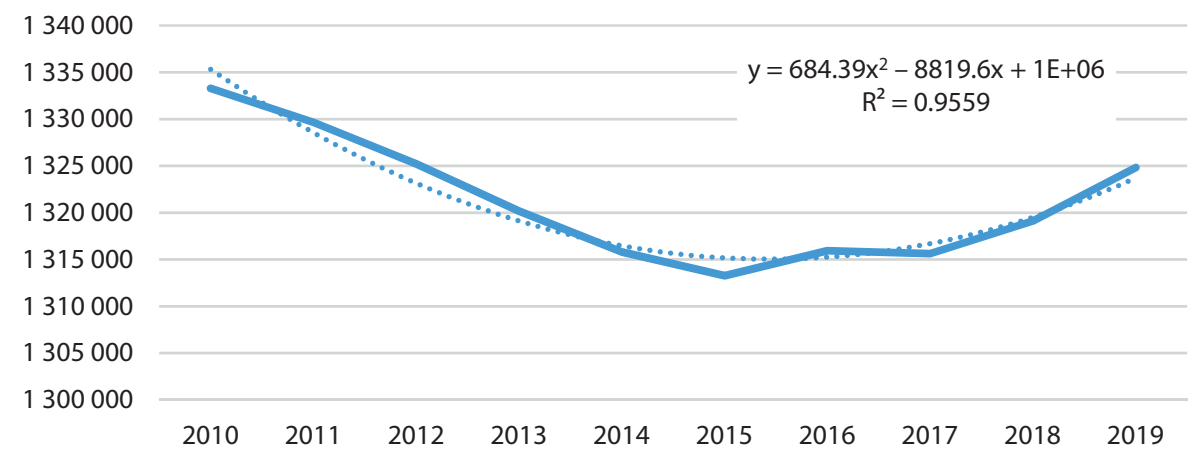

Figure 1. Empirical change of population size (1.01) and its approximation with a parabolic model 


\section{CHANGE IN THE SIZE OF ADOLESCENTS' AGE-GROUPS}

As the distribution of household and family types depends on the number of children, that is, on the fertility trends during the recent years, we regard the dynamics of sizes in adolescent's age-groups during the last ten years, see Figure 2.

The size of the youngest age-group has S-shaped form (parabola of the 3rd order) with the maximum in 2011 and the minimum in 2018 and a general decreasing tendency (total change $-5,7 \%$ ). This form is the reflexion of changes in the number of births during the period.

The size of the two next age-groups - 5-9 and 10-14 has been increasing and can be described by parabolae of the second order.

The size of the oldest age group, young people aged 15-19, years has decreased very strongly. The model is again a parabola of the second order.

The total change in the number of adolescents aged $<20$ years is similar to the change of total population, see Figure 3. The absolute number of adolescents in 2019 was $1 \%$ less than in 2000. Hence, the decrease in the number of adolescents was somewhat bigger than that of the total population, but changes in different age-groups are different as shown in Figure 3.

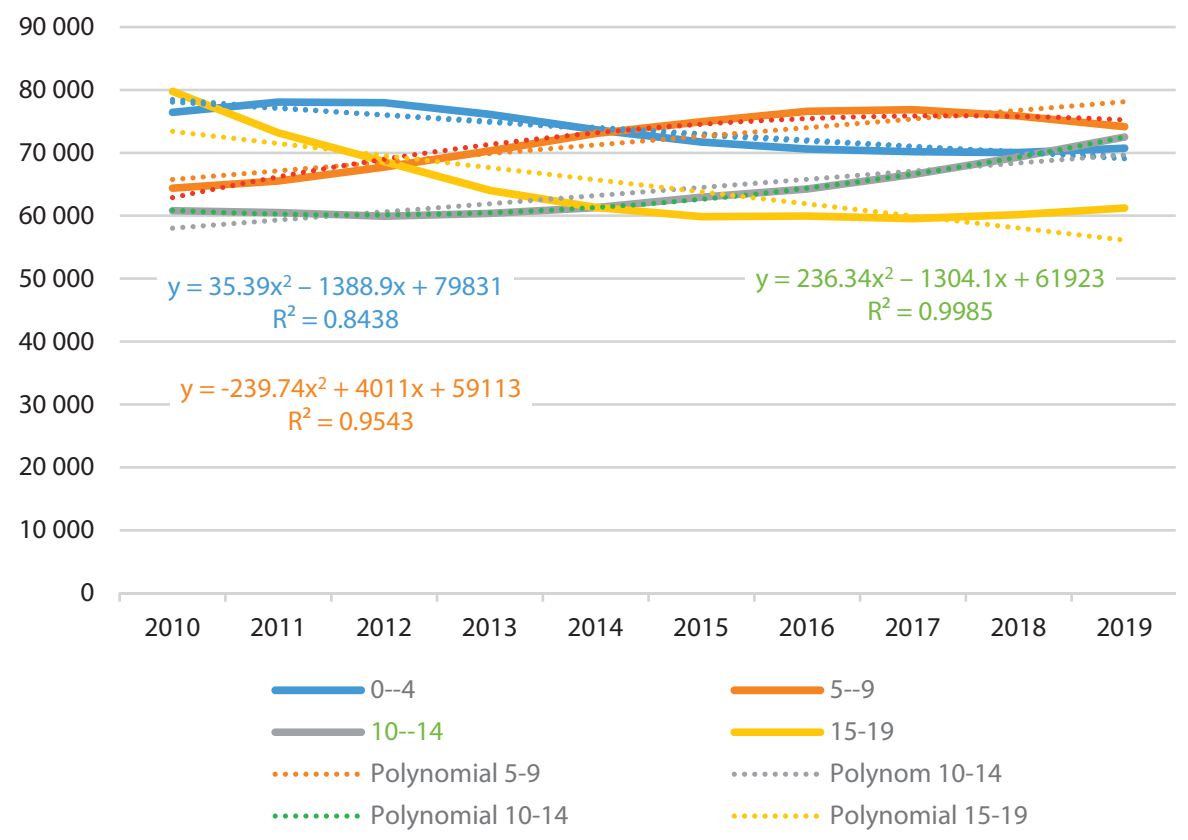

Figure 2. Changes in the size of children's age-groups 


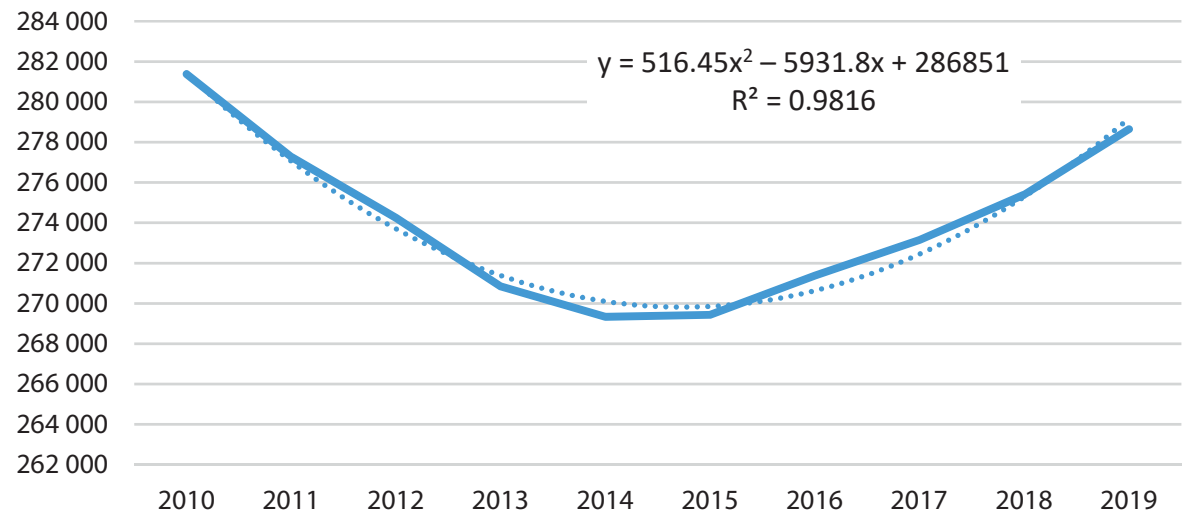

Figure 3. Change in the total number of adolescents

\section{CHANGES IN THE SIZE OF SENIOR AGE GROUPS}

The number of seniors, aged $65+$ has increased by $12.6 \%$, see Figure 4 . The change is not equal in all age-groups; the behaviour of the group 70-74 is especially exceptional, as from 2012-2017, this group included people who were born in the years of the Second World War. Notably big growth - 67\% occurred in the oldest age-group aged $85+$.

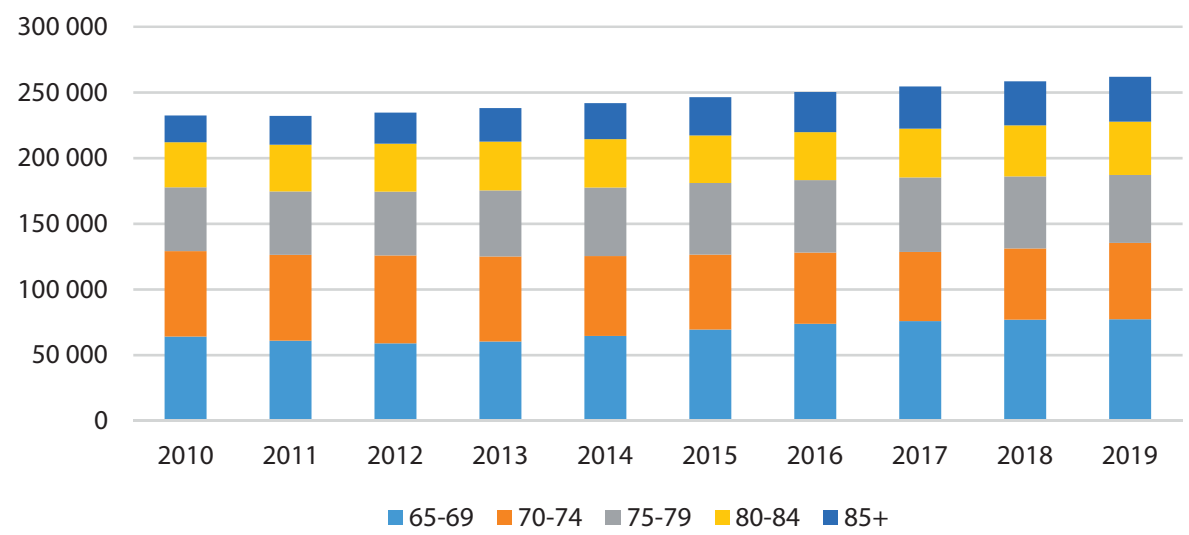

Figure 4. Dynamics in the number of senior age groups

\section{LEGAL AND DE FACTO FAMILY STATUS}

During the period 2010-2018 almost 55000 men and women married; the number of marriages per year increased 1.3 times from 2010 to 2018. At the 
same time 29000 marriages were divorced; the number of divorces increased by $7 \%$. The coefficient of the first marriage increased by almost 0.1 and had the value 0.47 for men and 0.53 for women, which is a considerably high value compared with the last decades in Estonia. The change can be described by a linear model showing a 1\% increase per year, see Figure 5.

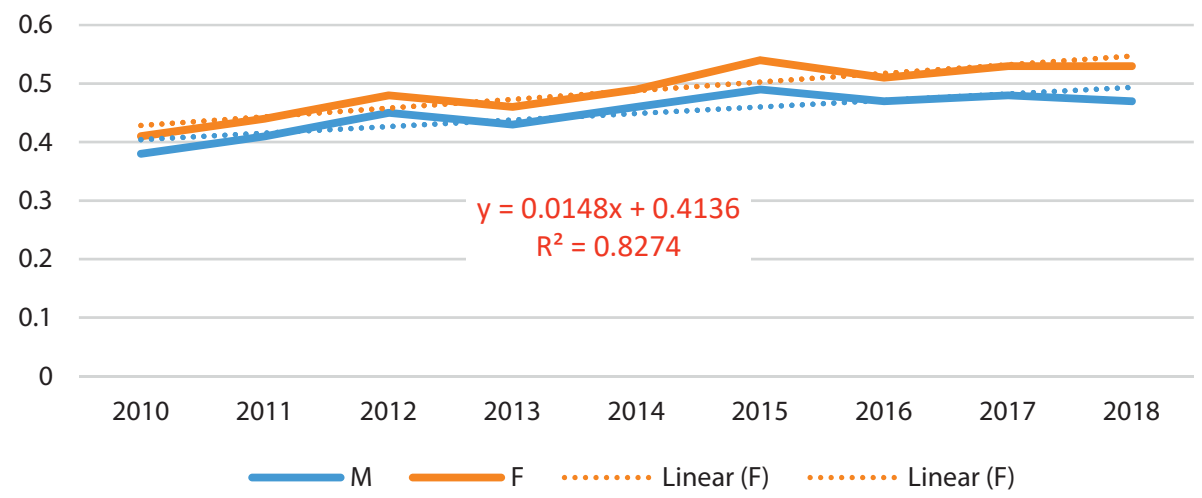

Figure 5. Coefficient of the first marriage in men and women

\section{CHANGES IN THE AGE OF MARRIAGE}

The age of the first marriage increased by almost two years and reached the value 29.6 years for brides and 32.1 years for grooms. Thus, the age of the first marriage increased by 3 months per year for men and 4 months per year for women, see Figure 6.

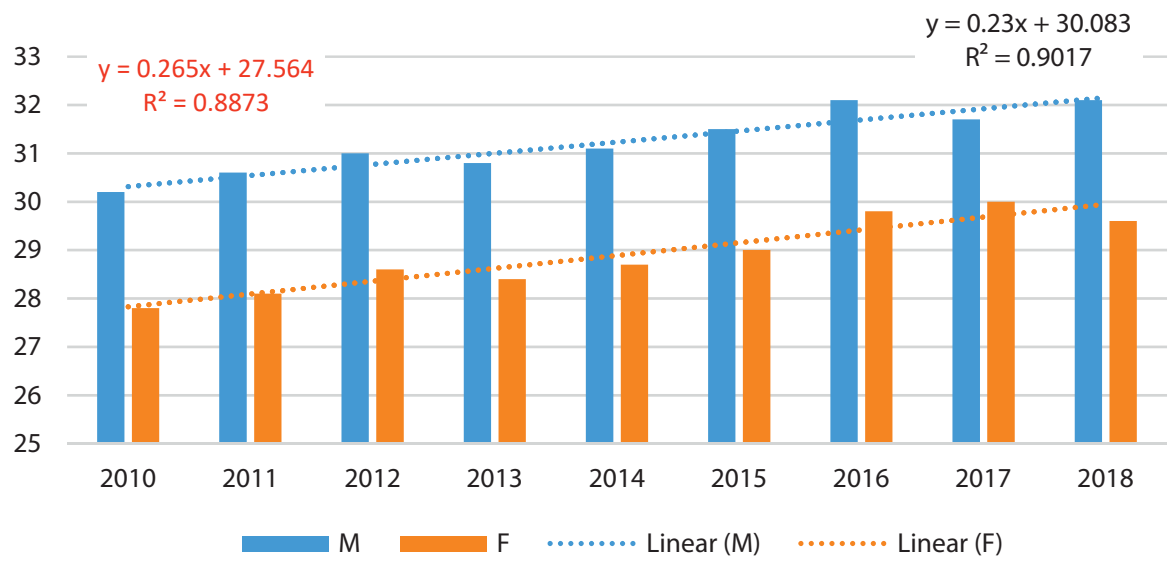

Figure 6. Age of the first marriage in men and women 
The increasing marrying activity and the rising age of marriage have an opposite impact on the number and share of married people in the population.

\section{COHABITATION}

The only source of information about non-registered cohabitation is available from census data, see Figures 7-9.

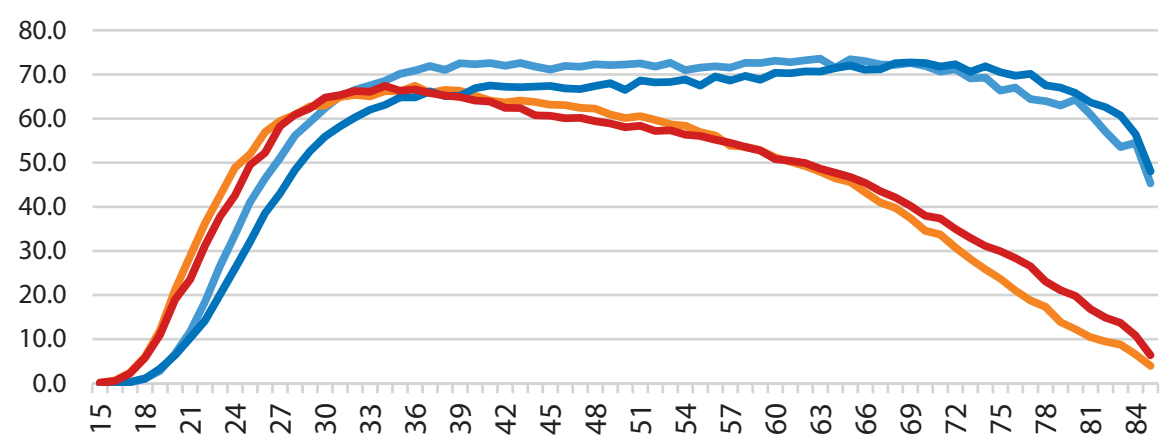

Figure 7. Men and women living with married or non-married partners in 2000 and in 2011

From Figure 7, we can see that the partnership patterns were quite similar at the time of both censuses, but there is a small shift towards later start. If we look the age when $50 \%$ of people live together with a partner, we can see that in 2000, this age was 26.8 years for men and 24.4 years for women. In 2011, this situation appeared when men were 28.4 and women 25.2 years old, which means that, in twelve years, the starting point of family life had shifted to more than one year later.

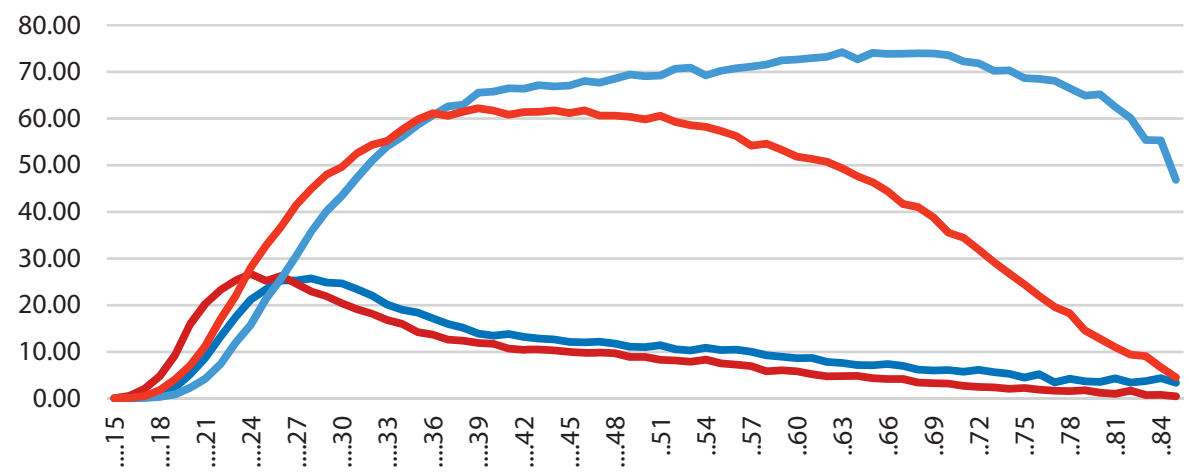

Figure 8. Family status of men and women in 2000, share in age groups 


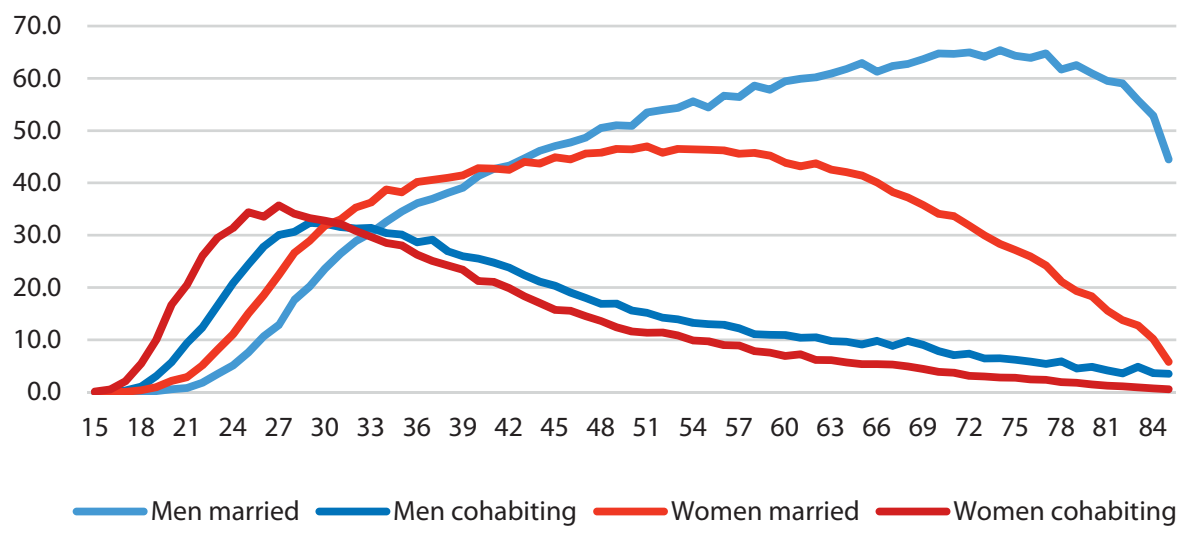

Figure 9. Family status of men and women in 2011, share in age-groups

The share of people living together with a partner among the population aged 15 years and more has also changed. In 2000, 56.5\% of men and $46.2 \%$ of women had partner; by 2011 this number had dropped and was $55.1 \%$ for men and $46.2 \%$ for women.

As there are many widows among aged women, we also compared the populations of age groups $15-49$ in both years. In $2000,-49.0 \%$ of men and $50.7 \%$ of women had a partner; in 2011, the share of men having a partner had dropped to $46.4 \%$, but the share of women having a partner had somewhat increased to $51.1 \%$.

To explain the different ratios of women and men, it is important to consider that the partners do not always belong to the same age group. Another reason explaining the change is that the ratio of women and men in fertile age has dramatically changed. In 2000, women were dominating among the population aged 15-49 years - per 100 men there were almost 104 women, but in 2011 the situation was the opposite: per 100 men there were 98 women. Here, the two main reasons were the more active emigration of young women and the dropped death rate (increased life expectation) of men.

The ratio of two partnership types - married couples and unmarried cohabiting couples - has also somewhat changed - in 2000, 19.5\% of all couples were not married, in 2011, this share was 31.0\%. Among the people aged 15-49 years, the share of unmarried partners was $28.5 \%$ in 2000 and $44.3 \%$ in 2011. 


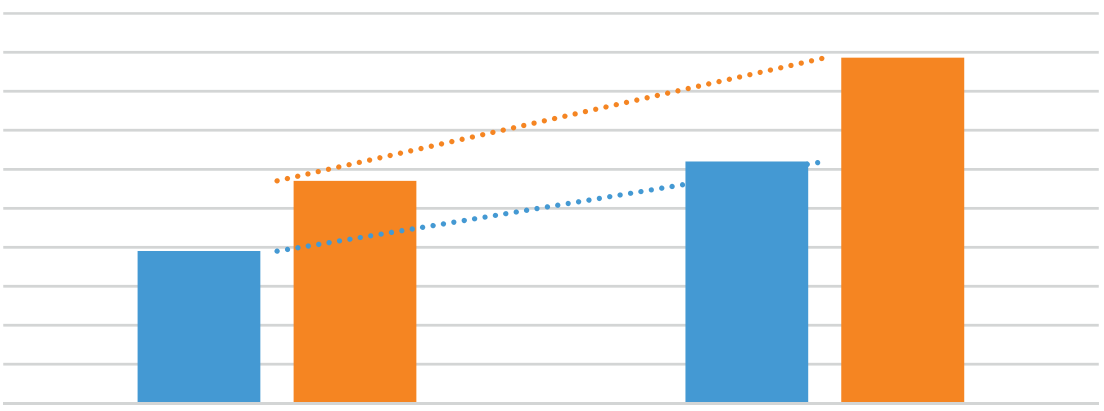

2000

All nuclear families Age 15-49

- Linear (All nuclear families) - Linear (Age 15-49)

Figure 10. Ratio of unmarried and married couples in 2000 and 2011

Probably the tendency of increase of unmarried couples continues but in a slowing tempo. Most married couples (60-78\%) have experienced cohabitation before marriage, see Figure 11.

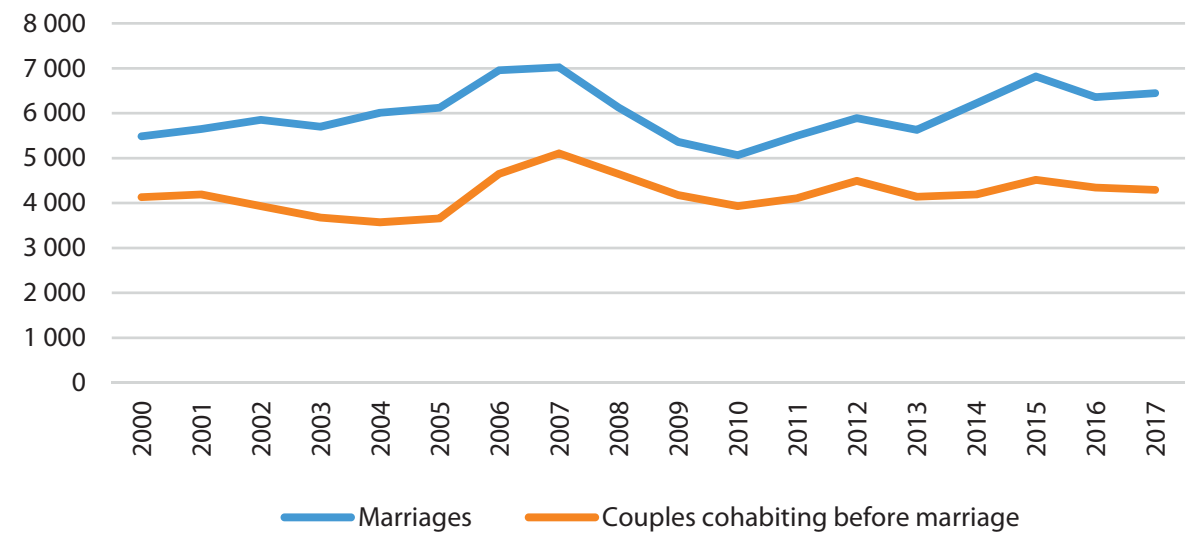

Figure 11. Number of marriages and couples who have cohabitated before the marriage

It is also quite common to marry after the couple already has a child or several children, see Figure 12. 


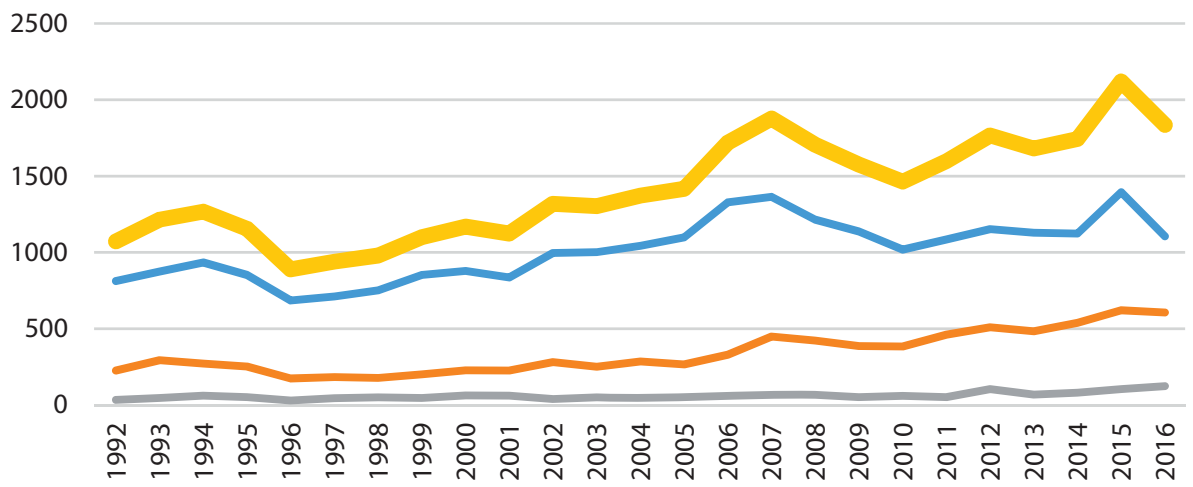

$\longrightarrow$ child 2 children $\longrightarrow 3+$ children Total

Figure 12. Marrying couples with common children

\section{DIVORCES}

The number of divorces was high in Estonia from the middle of the $20^{\text {th }}$ century already and increased extremely in the 1990s when the number of marriages dropped. Now, the ratio of divorces and marriages has gone down and has stabilized at the level of 50 divorces per 100 marriages, see Figure 13. Still, this fact does not demonstrate that half of marriages continue until the death of partners, as among all marriages, the number of second or third marriages for partners changes between 0.25 and 0.33 , having a modest tendency of falling.

Unfortunately, there is very few information on the stability of cohabitation; probably it is not higher than the stability of legal marriages.

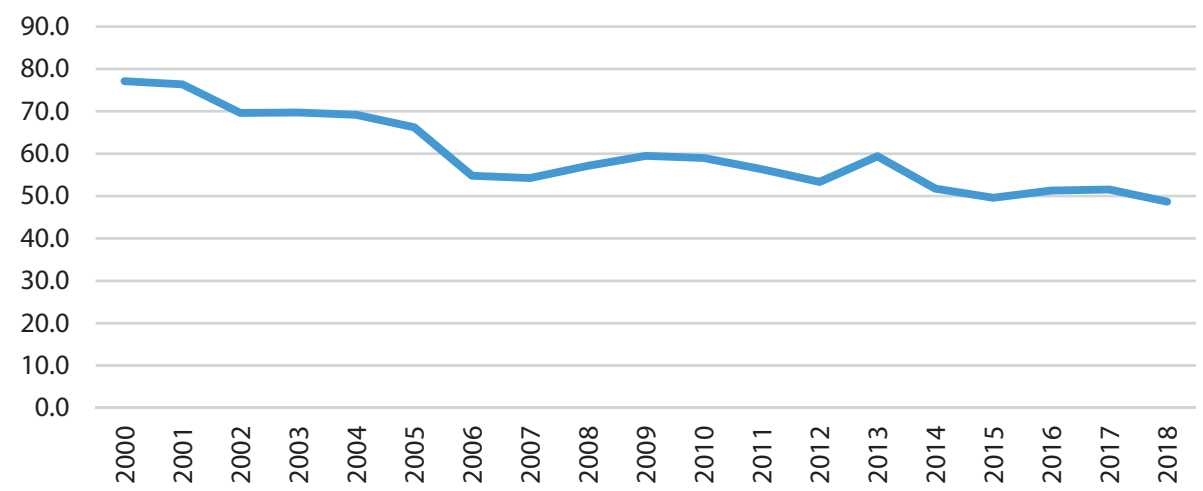

Figure 13. Number of divorces per 100 marriages. 
More than half of divorcing couples have common children. The average number of common children in divorcing couples is about 0.6 , and, consequently, almost 3000 children lose one of their parents each year; more often this is the father and a single-mother family arises.

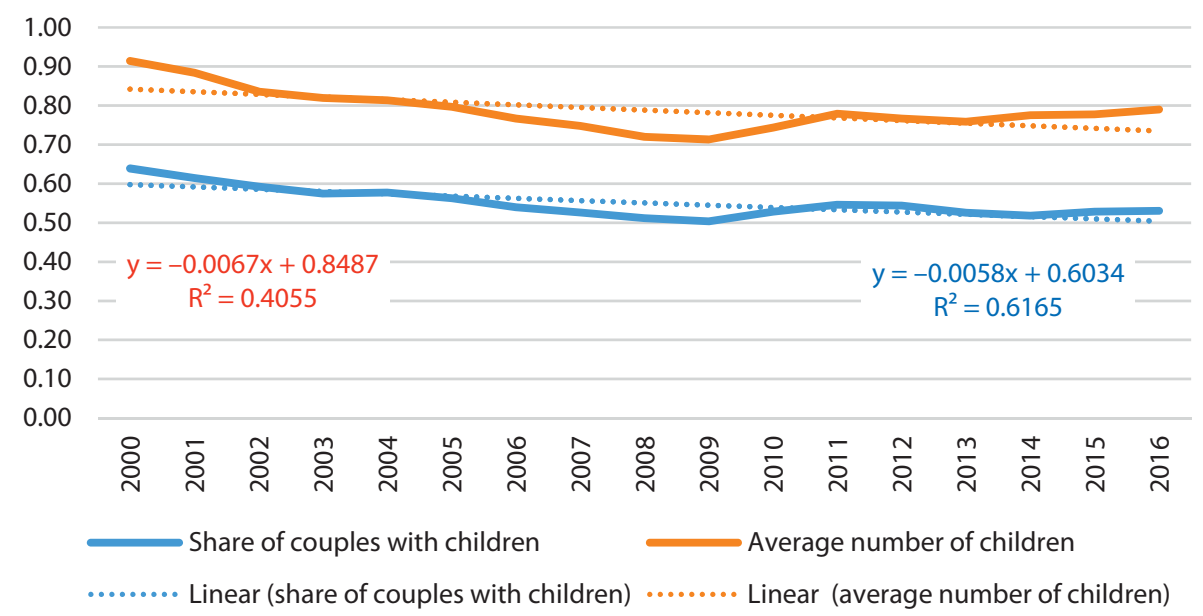

Figure 14. Children of divorced couples

\section{CHILDREN IN FAMILIES}

\section{Mother's family status when giving birth}

From the census in 2000, the distribution of family status of newborns' mothers has changed considerably, see Figures 10-12, but the share of married mothers has remained between $40 \%$ and $45 \%$, being the lowest (40.3) in 2011. From this year, the percentage of married mothers has increased, but the position reached in 2018 (43.3) is still lower than it was in 2000 (45.5).

A great change has happened in the share of cohabiting mothers. In 2000 their share was $28.8 \%$ and in 2014 almost twice more $-53.9 \%$. But this rate has not changed in the same direction all the time: from 2014, the share of cohabiting mothers has decreased and was $19.7 \%$ in 2018, still remaining the most common family status of child-bearing mothers.

The most dramatic change has happened in the number of women who have decided to give birth without having stabile partner, that is, as single mother. In 2000 their percentage was $26.3 \%$, and, during the period 2002 2003 , it increased to $36 \%$ but, after that, started to decrease quite rapidly, having its minimum value (4.2\%) in 2015. In 2018, the percentage of parturients 
who did not have a husband or a cohabiting partner was 7\%. Maybe big jumps in this time-series have some technical reasons, but it is still clear that the number of women who have chosen the way to have a child without a partner is less than $10 \%$.

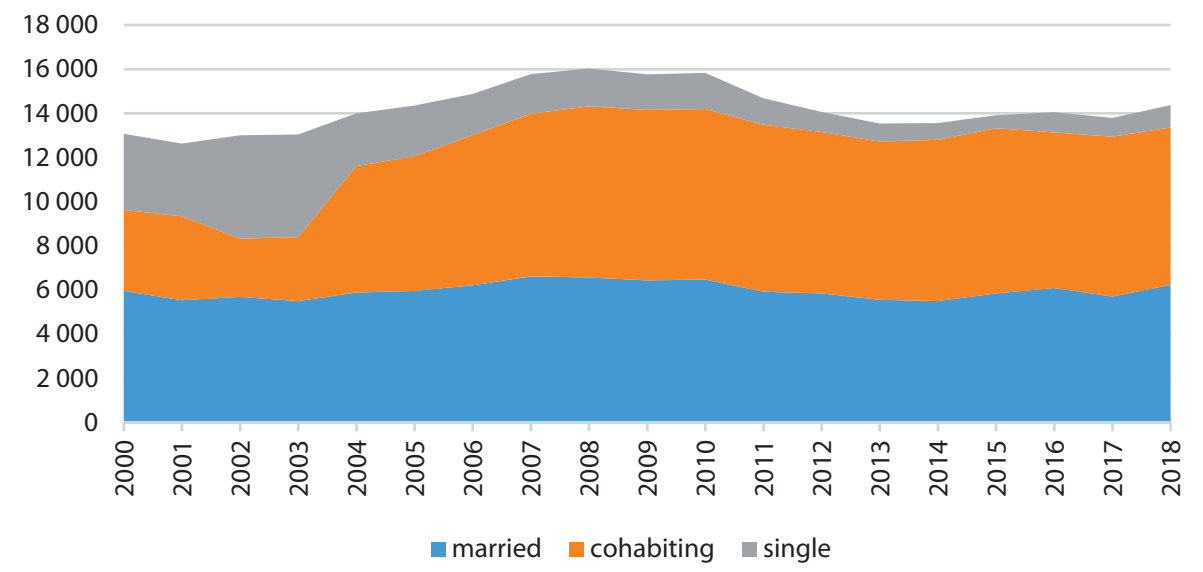

Figure 15. Newborn children by their mothers' family status

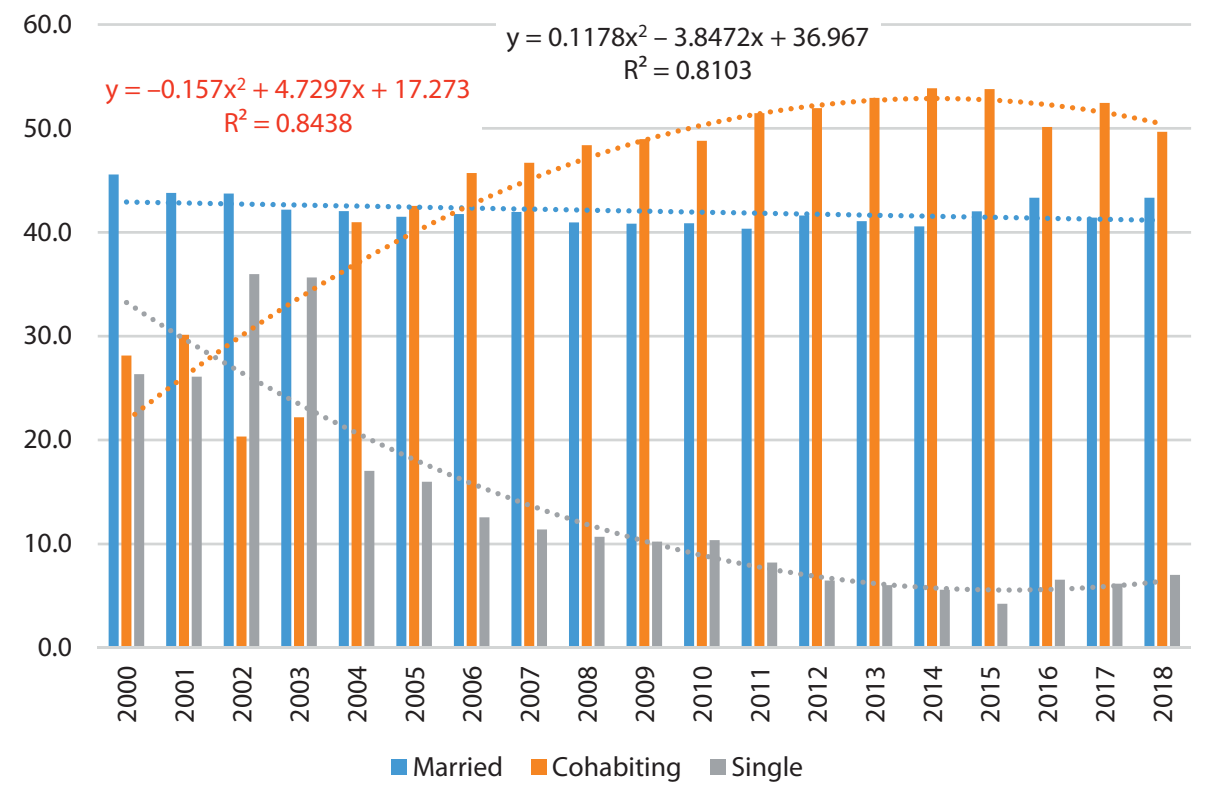

Figure 16. Trends of newborns' mothers' family status. Trends are polynomial for cohabiting and also single mothers, but linear for married mothers 


\section{AGE OF NEWBORNS' PARENTS}

The fact that mothers tend to postpone childbearing and that mothers' average age has increased for several years is generally known. Naturally, fathers' age has also increased, but, surprisingly, much less, see Figure 17. If the average age of women has increased by four years from 2000, the increase in men's age forms only $66 \%$ from this number. Especially remarkable is the stabilization of fathers' age during the period 2012-2018.

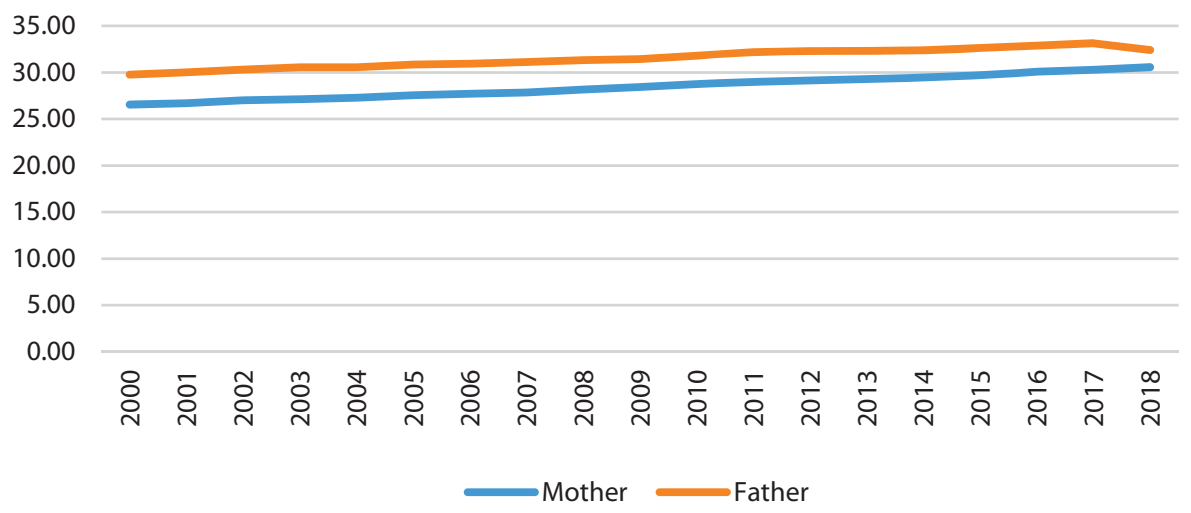

Figure 17. Average age of newborns' mothers and fathers

\section{BIRTH ORDER OF CHILDREN}

Birth order of children born in a year gives some information about the popular children's pattern in a certain time-period: if second children dominate among the newborns, then it is evident that single-children households are not very popular. In a similar way, the big share of third and following children might forecast the growing popularity of bigger families. During the last decade, the share of second children has almost reached the level of the share of first children, and the share of third children has also increased. Obviously, the biggest problem in Estonian family policy is postponing of the first birth, see Figure 18. 


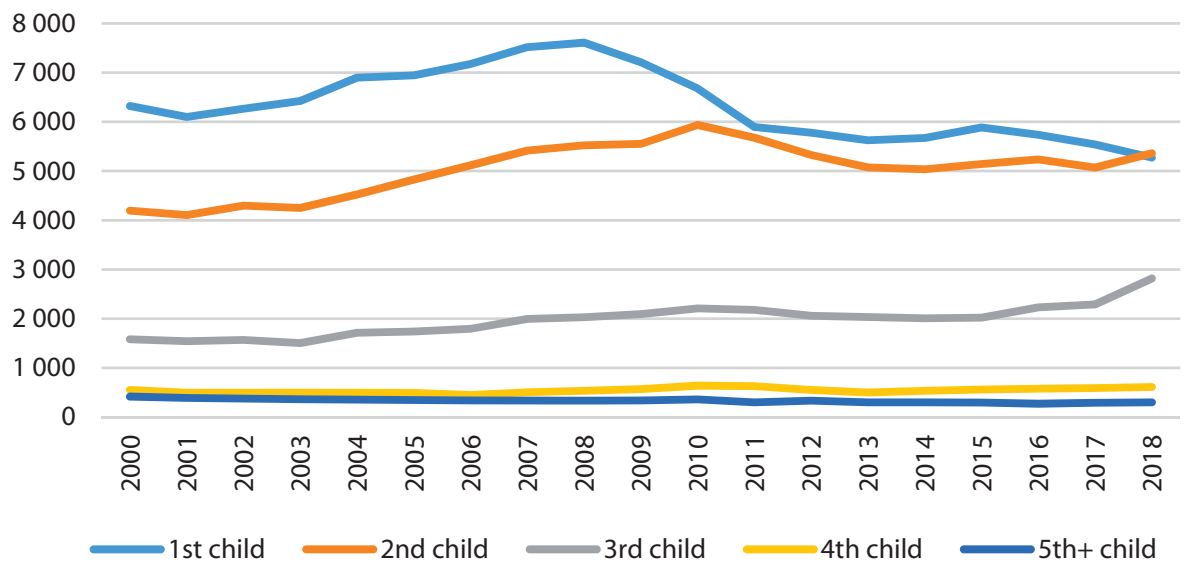

Figure 18. Trends in birth order of children

\section{TYPES OF HOUSEHOLDS AND NUCLEAR FAMILIES}

The traditional definition of the household is a group of people, usually living in a common dwelling, who share the available household facilities (common budget and food); a person living alone is also a household.

In register-based terminology, the household is a group of people (relatives or not) who live in a common dwelling. The household consists of nuclear families and additional household members. In the most typical case, the household has no nuclear families (this is single person's household) or one nuclear family, but households with two and also three nuclear families also exist - these are, usually, multigenerational households where grandparents, parents and children live together. In nuclear families, all members are related to each other. In the following text, we will mainly use the traditional definition of the household.

There exist the following types of nuclear families:

1. Married or cohabiting couple without children.

2. Married or cohabiting couple with a child or children.

a. At least one child is adolescent (aged less than 18 years).

b. All children are adults.

3. Single parent's family with an adolescent or adult child or children.

c. Single father's family.

d. Single mother's family.

To characterize the society, it is important to know the distribution of households and also the distribution of types of nuclear families. 


\section{Distribution of household types}

The following table gives the distribution of household and family types measured in the census of 2019.

Table 1. Typology of households and nuclear families

\begin{tabular}{|c|c|c|c|c|c|c|}
\hline \multirow[b]{3}{*}{ Single } & \multirow{2}{*}{\multicolumn{2}{|c|}{$\begin{array}{c}\begin{array}{c}\text { House- } \\
\text { holds } \quad \text { Members }\end{array} \\
\text { Nuclear families }\end{array}$}} & \multirow{2}{*}{\multicolumn{2}{|c|}{$\begin{array}{c}\begin{array}{c}\text { House- } \\
\text { holds Members }\end{array} \\
\text { Nuclear }+ \\
\text { additional ms }\end{array}$}} & \multirow{2}{*}{\multicolumn{2}{|c|}{$\begin{array}{c}\begin{array}{c}\text { House- } \\
\text { holds } \quad \text { Members } \\
\text { Total }\end{array} \\
\end{array}$}} \\
\hline & & & & & & \\
\hline & 239587 & 239587 & & & 239587 & 239587 \\
\hline $\begin{array}{l}\text { Hh without } \\
\text { nucleus }\end{array}$ & 10498 & 22202 & & & 10498 & 22202 \\
\hline $\begin{array}{l}\text { Married c without } \\
\text { children }\end{array}$ & 81230 & 162460 & 5162 & 15836 & 86392 & 178296 \\
\hline $\begin{array}{l}\text { Married with } \\
\text { adolescents }\end{array}$ & 57593 & 224622 & 4254 & 21271 & 61847 & 245893 \\
\hline $\begin{array}{l}\text { Married with } \\
\text { adult children }\end{array}$ & 29832 & 96521 & 2442 & 10465 & 32274 & 106986 \\
\hline Married total & 168655 & 483603 & 11858 & 47572 & 180513 & 531175 \\
\hline $\begin{array}{l}\text { Cohabiting os } \\
\text { without children }\end{array}$ & 30974 & 61948 & 2213 & 6829 & 33187 & 68777 \\
\hline $\begin{array}{l}\text { Cohabiting os } \\
\text { with adolescents }\end{array}$ & 39653 & 145222 & 2836 & 13427 & 42489 & 158649 \\
\hline $\begin{array}{l}\text { Cohabiting os } \\
\text { with adults }\end{array}$ & 5199 & 16631 & 435 & 1851 & 5634 & 18482 \\
\hline $\begin{array}{l}\text { Cohabiting os } \\
\text { total }\end{array}$ & 75826 & 223801 & 5484 & 22107 & 81310 & 245908 \\
\hline $\begin{array}{l}\text { Cohabiting ss } \\
\text { without children }\end{array}$ & 174 & 348 & 8 & 24 & 182 & 372 \\
\hline $\begin{array}{l}\text { Cohabiting ss } \\
\text { with adolescents }\end{array}$ & 24 & 90 & 4 & 17 & 28 & 107 \\
\hline $\begin{array}{l}\text { Cohabiting ss } \\
\text { with adults }\end{array}$ & 2 & 6 & 0 & 0 & 2 & 6 \\
\hline $\begin{array}{l}\text { Cohabiting ss } \\
\text { total }\end{array}$ & 200 & 444 & 12 & 41 & 212 & 485 \\
\hline $\begin{array}{l}\text { Single mother } \\
\text { with adolescents }\end{array}$ & 27551 & 70012 & 5857 & 20555 & 33408 & 90567 \\
\hline $\begin{array}{l}\text { Single mother } \\
\text { with adults }\end{array}$ & 33806 & 71743 & 3550 & 11387 & 37356 & 83130 \\
\hline $\begin{array}{l}\text { Single mother } \\
\text { total }\end{array}$ & 61357 & 141755 & 9407 & 31942 & 70764 & 173697 \\
\hline
\end{tabular}




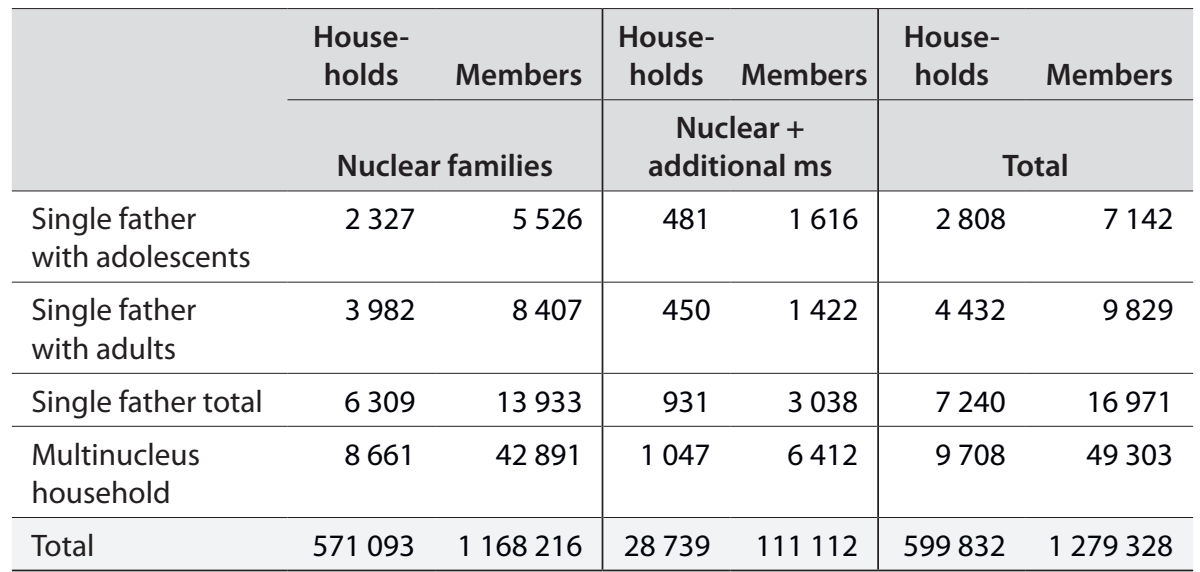

Explanations: Hh - household, ms - members, c - couple, os - opposite sex, ss - same sex; Hh without nucleus - household containing more than one member but no nuclear family, multinucleus household - household containing more than one nuclear family.

The share of different household types and their members is represented in Figure 19.

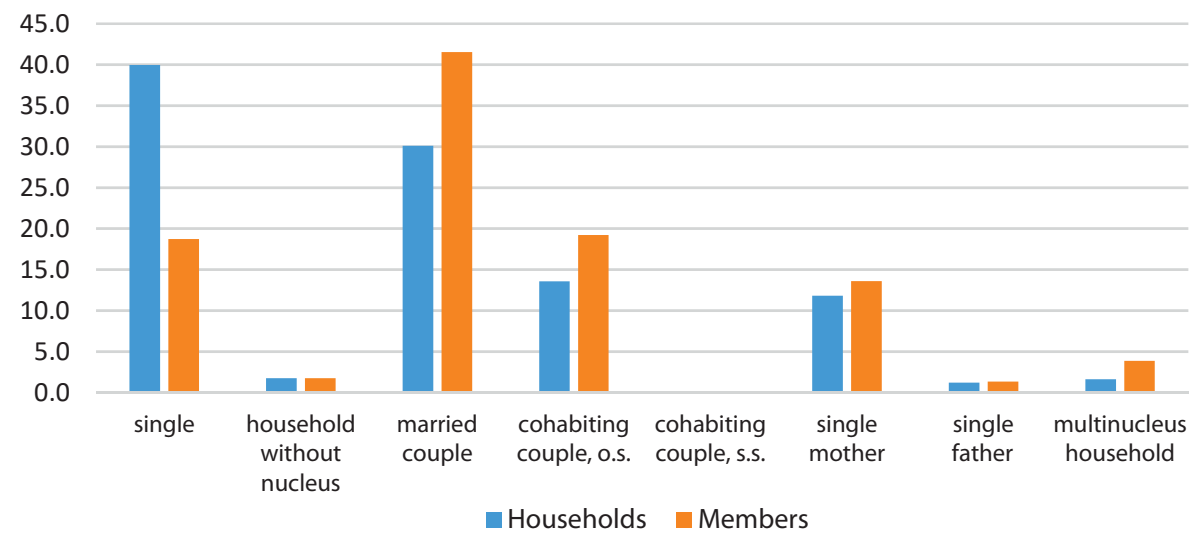

Figure 19. Distribution of household and family types, 2011

The most common household type in 2011 was the single person's household (39.9\%). Married couples' household type was on the second place (31.1\%). On the third and fourth place, there were households of cohabiting opposite sex couples (13.6\%) and single mothers' households (11.8\%). All other household types were very rare, covering in total less than $5 \%$ of all households. If family members are considered, the order is different. The biggest number of people (41.5\%) lived in married couples' households, $19.2 \%$ in households of 
cohabiting opposite-sex couples and $18.7 \%$ of all people lived alone - 94 thousand men and 145 thousand women, more than half of them widows. 6.3\% of all persons lived in single mothers' households, and 3.9\% of all household members lived in the biggest households which had two or more nuclei. Very few households had a cohabiting same-sex couple as the nucleus. This household type was measured in Estonia for the first time, and it is possible that it is under-reported and also under-covered. The households with several members but without a nucleus were also rather rare.

\section{ADDITIONAL MEMBERS OF HOUSEHOLDS}

More than 110000 persons are members of households but do not belong to the nuclear family constituting the household; that is $8.7 \%$ of the population. Often, they are relatives, e.g. parents of members of belonging to the nucleus. Sometimes they are also helpers or subtenants. Of the households with (married or unmarried) couples, about $7 \%$ have additional members. Most often the additional members belong to single-parent households; there are additional members in $15 \%$ of all cases. Obviously, single parents need more help from relatives and other people than the households of couples.

\section{CHILDREN IN HOUSEHOLDS}

Table 2. Households and families with adolescent children

\begin{tabular}{lrrr}
\hline Household type & $\begin{array}{c}\text { Nuclear } \\
\text { families }\end{array}$ & $\begin{array}{c}\text { Nuclear }+ \\
\text { additional } \\
\text { members }\end{array}$ & \multicolumn{1}{c}{ Total } \\
\hline Married couple with 1 child & 28277 & 2273 & 30550 \\
\hline Married couple with 2 children & 23408 & 1559 & 24967 \\
\hline Married couple with 3 or more children & 7472 & 615 & 8087 \\
\hline Cohabiting couple with 1 child & 22762 & 1729 & 24491 \\
\hline Cohabiting couple with 2 children & 14566 & 989 & 15555 \\
\hline Cohabiting couple with 3 or more children & 3694 & 284 & 3978 \\
\hline Single father with 1 child & 2134 & 446 & 2580 \\
\hline Single father with 2 or more children & 990 & 76 & 1066 \\
\hline Single mother with 1 child & 23121 & 4933 & 28054 \\
\hline Single mother with 2 or more children & 8878 & 1616 & 10494 \\
\hline Total & 135302 & 14520 & 149822 \\
\hline
\end{tabular}


Single mother with 2 or more children

Single mother with 1 child

Single father with 2 or more children

Single father with 1 child

Cohabiting couple with 3 or more children

Cohabiting couple with 2 children

Cohabiting couple with 1 child

Married couple with 3 or more children

Married couple with 2 child

Married couple with 1 child

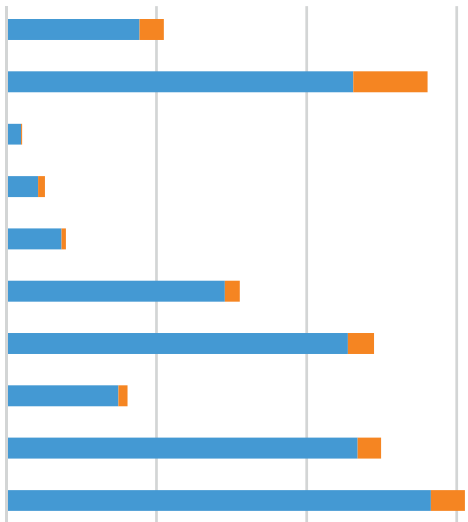

0

10000

20000

30000

40000

Nuclear families

Nuclear + additional members

Figure 20. Households with nuclear families containing adolescent children

In Table 2 and Figure 20, some households with children are missing - these are households without the family nucleus, e.g. the households of grandparents with children. The number of such households is small.

The decision to have the following child depends on the household and family type, see Figure 21.

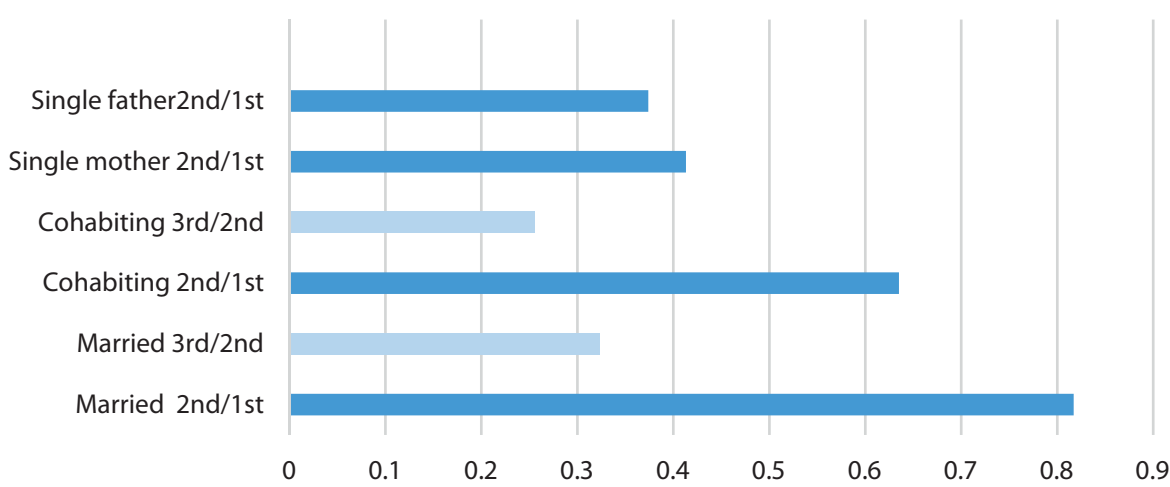

Figure 21. Frequency of having a following child in different household types

In married couples, the frequency of having the second child is the highest and in single parent households - the lowest. The frequency of having the third child (and following children) is also higher in married couples than in cohabiting couples. 


\section{CHANGE IN THE DEFINITION OF THE HOUSEHOLD}

As already mentioned, there are two possible definitions of the household, and, until now, we have used the traditional one. But the number of inhabited dwellings is about 50000 smaller than the number of traditional households, which means that the distribution of households by the number of their members will change when using the new definition of the household, see Figure 22.

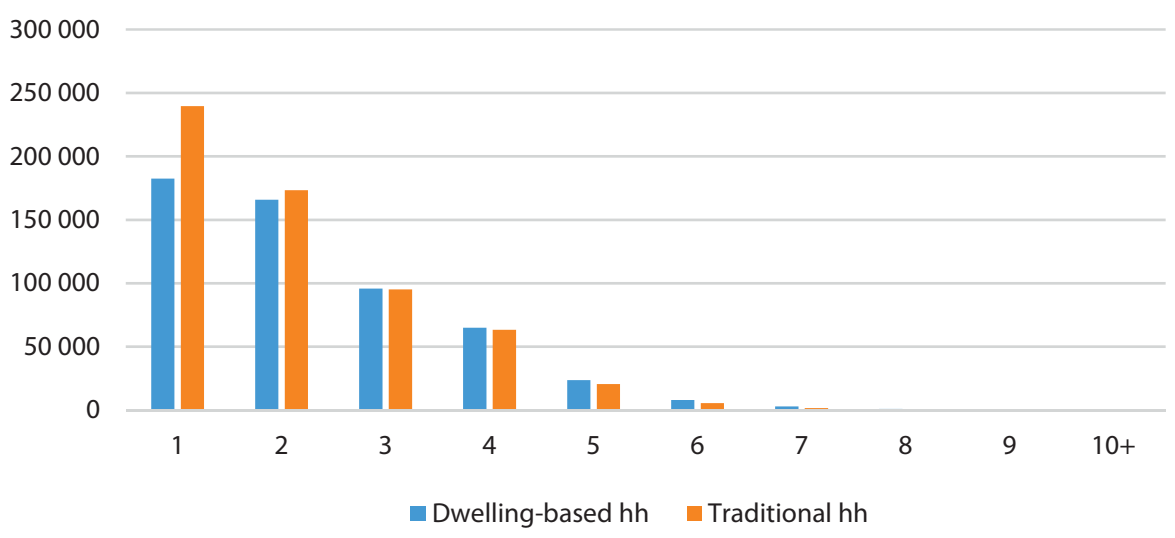

Figure 22. Distribution of household members according to two definitions of the household

It is evident that when the number of households decreases, the share of small households will decrease, and the share of large households will increase. The biggest decrease is in the number of one-person households: about $24 \%$ of them disappear. That means, 57 thousand single persons who live in the same dwelling with another household will be additional members of a household in the new statistical context.

The same happens with two-person households - their number decreases by $4 \%$, and more than 7000 two-person households will be joined with another household. As a result, the number of households with two or more nuclei increases.

The number of bigger households will increase - the number of households with six and seven persons will increase by $43 \%$ and $76 \%$ respectively; the number of households with more than seven persons will duplicate. 


\section{CONCLUSION}

The fact that the population of Estonia is changing is commonly known. The share of aged persons is increasing due to increasing life expectation; unmarried cohabitation is a normal lifestyle for the younger generation; the age of giving birth is increasing, and the number of children per woman is falling. Still, there are several effects that are not linear: during the last years the share of marriages has increased; the child-bearing pattern has also somewhat changed: the share of the third children is the highest compared with the last twenty years.

The household structure has been quite stable during the decade, but due to the change in the definition, the average number of family members will increase, and the share of single persons fall. It is important to notice that this change is rather formal.

\section{REFERENCES}

All statistical materials are taken from the open database of Statistics Estonia, https://www.stat.ee/

\section{Address for correspondence:}

Ene-Margit Tiit

Institute of Mathematics and Statistics

University of Tartu, Tartu, Estonia

Narva 18, 50409, Tartu, Estonia

E-mail: ene.tiit@ut.ee 